\title{
$\mathrm{GM}$ 작물 연구개발 및 상용화 동향
}

조정일 $^{1+}$ - 박성한 ${ }^{2+} \cdot$ 이강섭 $^{3} \cdot$ 김수민 $^{4} \cdot$ 임수미 $^{4} \cdot$ 김연식 $^{4} \cdot$ 박수철 $^{4}$

${ }^{1}$ 농촌진흥청 국립식량과학원, ${ }^{2}$ 한국 $\mathrm{BASF},{ }^{3}$ 농촌진흥청 국립농업과학원, ${ }^{4}$ 서울대학교 그린바이오과학기술연구원

\section{Current Status of GM Crop Development and Commercialization}

\author{
Jung-II Cho ${ }^{1 \dagger}$, Sung-Han Park ${ }^{2 \dagger}$, Gang-Seob Lee ${ }^{3}$, Su-Min Kim4, Su-Mi Lim4, Youn-Shic Kim ${ }^{4}$, and Soo-Chul Park ${ }^{4 *}$ \\ ${ }^{1}$ Crop Production and Physiology Division, National Institute of Crop Science, Rural Development Administration, Wanju 55365, Republic \\ of Korea \\ ${ }^{2}$ Regulatory Affairs Seeds \& Traits, BASF in Korea, Seoul 07071, Republic of Korea \\ ${ }^{3}$ Department of Biosafety, National Academy of Agricultural Science, Rural Development Administration, Jeonju 54874, Republic of Korea \\ ${ }^{4}$ Institutes of Green-bio Science \& Technology, Seoul National University, Pyeongchang 25354, Republic of Korea
}

\begin{abstract}
The global area of GM Crops continued to grow in 2018 and reached 191.7 million hectares. Twenty-six countries approved biotech crops for planting and an additional 44 countries $(18+26$ EU countries) officially imported biotech crops for food, feed, and processing, meaning that biotech crops are now commonly accepted in those countries. First-generation GM seed is being commercialized by global agricultural companies in advanced countries such as the United States and parts of Europe. The fact that more than $90 \%$ of first-generation GM seeds, which have been commercialized for 20 years, are both insect resistant and herbicide resistant proves that they continue to have an effect on improving agricultural productivity and increasing farmers' incomes. As the effectiveness of GM crops has been proven and technology has been developed, the GM crop development trend has recently changed. In other words, it has moved from being producer-oriented to benefiting both farmers and consumers. In Korea, the National Program for GM Crops (NCGC), one of the Next-Generation BioGreen 21 Programs organized by Rural Development Administration (RDA), was established in 2011 to develop biotech crops that will be used in the future to solve our agricultural problems. To accomplish this mission, the NCGC carried out the exploration of useful functional genes, the development of qualified events, and the safety assessment of developed events. Here, we introduce the current status of GM crop development and commercialization in the world and in Korea.
\end{abstract}

Keywords GM Crops, Biotech Crops, Current status of GM crop

Received on December 17, 2019. Revised on January 26, 2020. Accepted on February 8, 2020.

* Corresponding Author (E-mail: scpark1@snu.ac.kr, Tel: +82-33-339-5836, Fax: +82-33-339-5825).

+ These authors contributed equally.

\section{서 언}

유전자변형작물(Genetically Modified Crop)로 불리는 GM 작물의 전 세계 재배면적은 2018년에도 계속 증가하여 1억 9,170 만 ha에 도달했다. 2018년 현재 26개국이 재배용으로 GM작물을 승인했으며, 추가 44 개국 $(18+26 \mathrm{EU}$ 국가 $)$ 은 공식적으로 식품, 사료 및 가공용으로 $\mathrm{GM}$ 작물을 수입하는 등 이미 전 세계적으로 $\mathrm{GM}$ 작물이 일반적으로 상용화되고 있음을 의미한다. 1 세대 $\mathrm{GM}$ 종자는 미국과 유럽이 글로벌 종자회사를 중심으로 연구개발과 상용화를 주도하고 있다. 20년간 상용화 된 1세대 GM 종자의 $90 \%$ 이상이 해충 저항성 또는 제초제 내성 형질이라는 사실은 이들 $\mathrm{GM}$ 작물이 농업 생산성 향상과 농민 소득 증대에 지속적으
로 영향을 미치고 있음을 증명한다. 이와 같이 $\mathrm{GM}$ 작물의 효과가 입증되고 기술이 점점 발전됨에 따라 최근 $\mathrm{GM}$ 작물 개발 추세가 바뀌고 있다. 즉, 농업형질 개선이라는 생산자 중심 목표에서 농민과 소비자 모두에게 이익이 되는 방향으로 연구개발과 상용 화가 확대되고 있다. 이러한 글로벌 동향과는 달리 우리나라의 상업용 GM작물 개발은 선진국 대비 상당히 기술격차를 보이고 있다. 대한민국에서는 농촌진흥청이 주관한 차세대 BioGreen21 프로그램 중 하나인 GM작물개발사업단(National Center for GM Crops, NCGC)이 2011년에 설립되어 우리가 가장 취약한 분야인 상업용 $\mathrm{GM}$ 작물 개발을 시작하여 우리의 농업 문제를 해결하기 위해 미래에 활용될 생명공학 작물 개발을 본격적으로 시작하였다. 이를 위해 NCGC는 유용 유전자 탐색, 동 유전자가 
도입된 유용 형질전환 작물 개발과 이들의 해외시장 진출을 위한 고부가 글로벌 $\mathrm{GM}$ 작물 개발 등의 연구사업을 수행하였다. 이에, 현재 진행되고 있는 글로벌 및 국내 GM작물 개발 및 상업화 현황과 전망을 아래와 같이 소개하고자 한다.

\section{$\mathrm{GM}$ 작물 상업화 현황}

1953년 Watson \& Crick이 DNA 구조를 밝혀낸 이후 분자생 물학의 비약적인 발전을 바탕으로 1994년 GM 면화, 1996년 $\mathrm{GM}$ 대두/옥수수가 개발되면서 1996년부터 본격적인 상업화가 시작되었다. 상용화 23년째인 2018년에는 26개국에서 1억 9,170 만 ha의 GM작물이 재배되어 2017년 1억 8,980만 ha보다 $1 \%$ 가 증가하였다. GM작물은 재배면적이 170만 ha에 불과했던1996 년과 비교하여 112 배까지 증가하는 등 세계에서 가장 빠르게 채택된 농업기술의 하나로서, 총 26개국에 의해 재배되고 있다. 또한 추가 44 개국( 18 개국 $+26 \mathrm{EU}$ 국가들)은 식품, 사료, 가공을 위해 $\mathrm{GM}$ 작물을 수입하고 있어 총 70개국이 현재 $\mathrm{GM}$ 작물을 채택하고 있다(ISAAA Brief 53,54). 현재 상업화된 $\mathrm{GM}$ 작물 중 면화, 대두, 카놀라, 옥수수의 4개 종목은 Table 1과 같이 $\mathrm{GM}$ 작물 재배율이 $30 \%$ 이상이며 콩과 면화는 $70 \%$ 이상 $\mathrm{GM}$ 작 물로 재배되고 있다(ISAAA Brief 54).

세계 종자시장에서의 $\mathrm{GM}$ 종자 상업화 비중도 지속 증가 중이다. 세계 상업종자시장에서 2013년을 기점으로 $\mathrm{GM}$ 종자 판매액이 일반 종자의 판매액을 넘어서고 있다. 2016년에는 전체 종자 판매량이 약 370 억 달러에 이르고 이 중 $\mathrm{GM}$ 종자 판매액은 204억 달러 수준으로 $55 \%$ 수준에 이르고 있다. 현재 아프리카대륙과 아시아에서 $\mathrm{GM}$ 작물 재배가 확대되고 있어 $\mathrm{GM}$ 종자의 상업화 비중은 더욱 증가할 전망이다.

\section{$\mathrm{GM}$ 작물 연구개발 동향 변이}

1 세대 $\mathrm{GM}$ 종자는 주로 생산자 중심의 농업형질 개선에 중점 을 두고 개발되었다. 현재까지 22년간 상용화되고 있는 1세대 $\mathrm{GM}$ 종자의 $99 \%$ 이상이 해충저항성과 제초제내성 두 가지 형질 이었지만, 현재 이들 이외에 지구온난화 등 기후변화에 대응하기 위한 건조저항성 $\mathrm{GM}$ 작물과 질소비료 저감이 가능한 $\mathrm{GM}$ 작물 개발이 적극 추진되고 있다. 건조저항성 $\mathrm{GM}$ 옥수수의 경우는 2013년 미국에서 최초 상업화된 이후 캐나다, 브라질, 남아프리 카공화국으로 등 다른 국가로 상업화 재배가 확산되고 있다. 반면, 최근 $\mathrm{GM}$ 종자 연구개발 동향이 급속도로 변화되고 있다. 기존의 생산자 중심에서 생산자와 소비자가 동시에 혜택을 주는 2,3 세대 GM작물 개발과 상업화가 활발히 이루어지고 있다. 또한, 다국적 기업 주도에서 각 국가별 농업의 문제해결의 방안으 로서 $\mathrm{GM}$ 작물이 개발되거나 식품가공업체 등 소규모 기업들이 자체 애로사항 해결을 위해 자체적으로 연구개발과 상업화를 추진하고 있다. 이외에 사료용/식품가공용에서 식용 GM작물의 상업화가 확대되고 있는 것도 주요한 변화로 다가오고 있다. 즉, $\mathrm{GM}$ 작물의 실용화가 점점 더 우리의 실생활로 확산되어 다가오고 있다는 것을 의미 한다(Cho et al. 2016, Kim et al. 2018).

\section{소비자/수요자 지향적 GM작물 개발 및 상용화 사례}

농산물의 경우 가공이나 유통과정에서 손실을 입는 경우가 많다. 이런 어려움 해결을 위한 GM작물 개발이 활발히 진행되고 있다. 대표적인 소비자 지향적 $\mathrm{GM}$ 작물의 상업화 사례는 갈변방 지 GM 감자다. 미국 냉동감자회사인 Simplot社는 저장 및 가공 시 상처로 인한 갈변현상 방지 감자를 개발한데 이어, 감자를 고온에서 오래 튀길 경우 발생한다는 잠재적 발암물질(아크릴아 마이드) 함량을 감소시키는 $\mathrm{GM}$ 감자를 자체적으로 개발하였다.

Table 1. Global area of biotech crops, 2017 and 2018

\begin{tabular}{|c|c|c|c|c|}
\hline Crop & \multicolumn{2}{|c|}{2017} & \multicolumn{2}{|c|}{2018} \\
\hline Corn & 59.7 & 32 & 58.9 & 30 \\
\hline Soybean & 94.1 & 77 & 95.9 & 78 \\
\hline
\end{tabular}


Innate $^{\mathrm{TM}}$ 라고 명명된 이 1세대 $\mathrm{GM}$ 감자는 2014년 11월 미농무부 에서 상업적 재배 승인을 받은 후 미국에서 2015년 처음으로 160 ha가 재배되었고 2016년에 2500 ha, 2017년 1618 ha로 그 재배면적이 증가되었다. 2 세대 Innate 감자는 1 세대 innate 감자에 아일랜드 감자 기근의 원인균이었던 잎마름병, 즉 감자역 병에 대한 저항성 형질이 추가된 것이다. 이 2세대 Innate 감자는 2016년 1월 12일 미국 FDA와 USDA에서 식용 및 재배가 최종 승인된 후 2017년도에 미국에서 809 ha가 재배되었으며, 2018년 도에는 $900 \mathrm{ha}$ 로 재배면적이 증가되었다. 이 2세대 Innate 감자는 병저항성과 함께 고온 조리 시 암유발인자인 아크릴아마이드 (acrylamide) 생성저감 형질도 동시에 가짐으로써, 소비자의 이 익과 농업의 지속 가능성을 모두 충족 가능하게 하는 생명공학 기술개발 최근 트랜드의 사례로 소개되고 있다(Cho et al. 2016, ISAAA Brief 53. 2018, Kim et al. 2018).

최근에는 미국에서 발암물질인 아플라톡신(aflatoxin)을 생산 하는 곰팡이 제어가 가능한 $\mathrm{GM}$ 옥수수를 개발하여 생산자인 농부와 소비자들의 큰 반응을 얻고 있다. 매년 전 세계적으로 1,600 만 톤의 옥수수가 아플라톡신 오염으로 버려지고 있다고 하는데. 연구진은 RNA 간섭(RNA interference)기술을 이용하 여 곰팡이의 아플라톡신 생산을 차단하는 물질을 GM작물에서 생산하도록 하였다. 연구진들은 같은 방법으로 쌀, 대두, 땅콩과 같이 아플라톡신 오염이 쉽게 발생하는 다른 작물에도 적용할 수 있을 것이라고 밝히고 있다. 이외에, 이스라엘 농업 연구소 (Agricultural Research Organization)의 과학자들이 숙성 호르 몬인 에틸렌(ethylene) 유전자를 억제시켜 부패를 줄이고 유통기 한을 연장할 수 있는 $\mathrm{GM}$ 바나나를 개발하는 등 생산자뿐만 아니라 기술 수요자와 소비자에게도 혜택을 부여하는 다양한 GM작물 개발이 이루어지고 있다(Kim et al. 2018).

\section{농업용에서 산업소재 생산용으로 확대}

질병예방을 위한 백신용 $\mathrm{GM}$ 작물의 상업화도 이미 현실화 되고 있다. 고부가가치 유용물질의 대량 생산을 위하여 유전자변 형 식물체를 생산공장으로 활용하고자 하는 방식을 분자농업 (Molecular Farming)이라 말한다. 이러한 분자농업에서 가장 주목 받는 연구 분야 중 하나가 섭취를 통해 질병을 사전 예방할 수 있는 식물 경구백신의 개발이다. 형질전환 식물을 이용한 경구 백신은 1995년 Science 잡지에 병원성대장균(enterotoxigenic E. coli)의 항체를 생산하는 형질전환 감자를 쥐에 사료로 먹인 결과 효율적인 면역반응을 유도한 결과가 발표되면서 성공 가능
성이 주목 받기 시작되었다. 이후 2002년에는 설사면역제를 생산하는 GM 토마토가 개발되어 타임지가 선정한 2002년 세계 20대 발표의 하나로 선정되기도 하였다. 문제는 식물세포에서 단백질을 생산할 경우 인체에서 활성이 가능한 복잡한 구조의 단백질 합성에 어려움이 있을 수 있으며, 식물체 내에서의 단백질 발현율이 낮아 경제성이 문제가 되는 등 해결해야 할 여러 문제가 있다는 점이다. 이런 이유로 현재는 형질전환식물보다는 유전자 가 형질전환된 식물세포를 인공 배양기에서 대량 배양한 후 목적하는 단백질이나 유용 물질을 생산하는 방식으로 실용화가 진행되고 있다. 이와 같이 아직 상업화에 이르지는 못했지만 현재도 광견병, 콜레라, 구제역, 에볼라바이러스 등 인류를 위협 하는 신형 질병을 예방하기 위한 식물 경구백신이 지속적으로 개발 중이며 앞으로 수년 내에 상업화가 이루어 질 것으로 예상되 고 있다. 이러한 연구는 기존의 다국적 종자기업이 아닌 다국적 의약품 회사, 미국/유럽/이스라엘/일본 등 기술력을 중심으로 설립된 소규모 생명공학기업, 또는 각 국가의 대학 및 국공립연구 소를 중심으로 활발히 진행되고 있다. 즉, 의약품 원료를 기존의 세포배양이 아닌 GM작물을 통해 지속적이고 안정적으로 대량 생산하겠다는 전략을 선택하고 있는 것이다. 개발자들은 밀폐식 격리온실 재배를 통해 안전성이 담보되고 의약품 생산 용도이므 로 상업화에도 큰 문제가 없을 것으로 전망하고 있다(Kim et al. 2018, Kim et al. 2019).

반면 동물용 의약품 생산 $\mathrm{GM}$ 작물의 상업화는 2013년에 이미 이루어졌다. 일본 경제산업성 산하 산업기술종합연구소(AIST) 는 개 $(\operatorname{dog})$ 의 치주염을 치료하는 항바이러스 인터페론을 생성하 는 GM 딸기를 개발하여, 2013년에 상품등록을 마치고 2014년 3 월에 마침내 상업용 판매를 시작하였다. 이 $\mathrm{GM}$ 딸기는 밀폐형 온실에서 격리재배하고 수확한 딸기를 재료로 의약품을 제조하 고 있다(Fig. 1). 이와 같이 비록 동물용이지만 질병 치료용 유전 자변형작물의 재배가 상용화 된 것은 매우 고무적인 일이다. 향후 다양한 질병에 고통 받고 있는 인류의 문제를 해결하기 위한 보다 값싸고 안전한 인간 질병 예방 및 치료용 $\mathrm{GM}$ 작물의 상용화 시대도 곧 열릴 것으로 전망된다. 일본은 이미 2007년에 삼나무 꽃가루 알레르기 예방백신을 생산하는 $\mathrm{GM}$ 벼를 개발하 고, 2016년 현재 상용화에 필요한 임상실험을 진행하고 있다 (Cho et al. 2016, Kim et al. 2018).

\section{국가 또는 소규모 기업에서 연구개발과 상업화 적극 추진}

방글라데시의 해충저항성 GM 가지 상업화는 자국의 애로사 
항 해결을 위한 국가차원의 $\mathrm{GM}$ 작물 연구개발과 상업화 추진의 대표적 사례이다. 방글라데시에서 중요한 채소작물인 가지는 15 만 영세농가가 약 5 만 ha에서 재배하고 있는데, 재배 품종들이 해충인 FSB (fruit and shoot borer)의 공격에 매우 취약하여 $70 \%$ 정도의 재배손실을 준다. 이 해충은 과육 및 줄기 가해충으

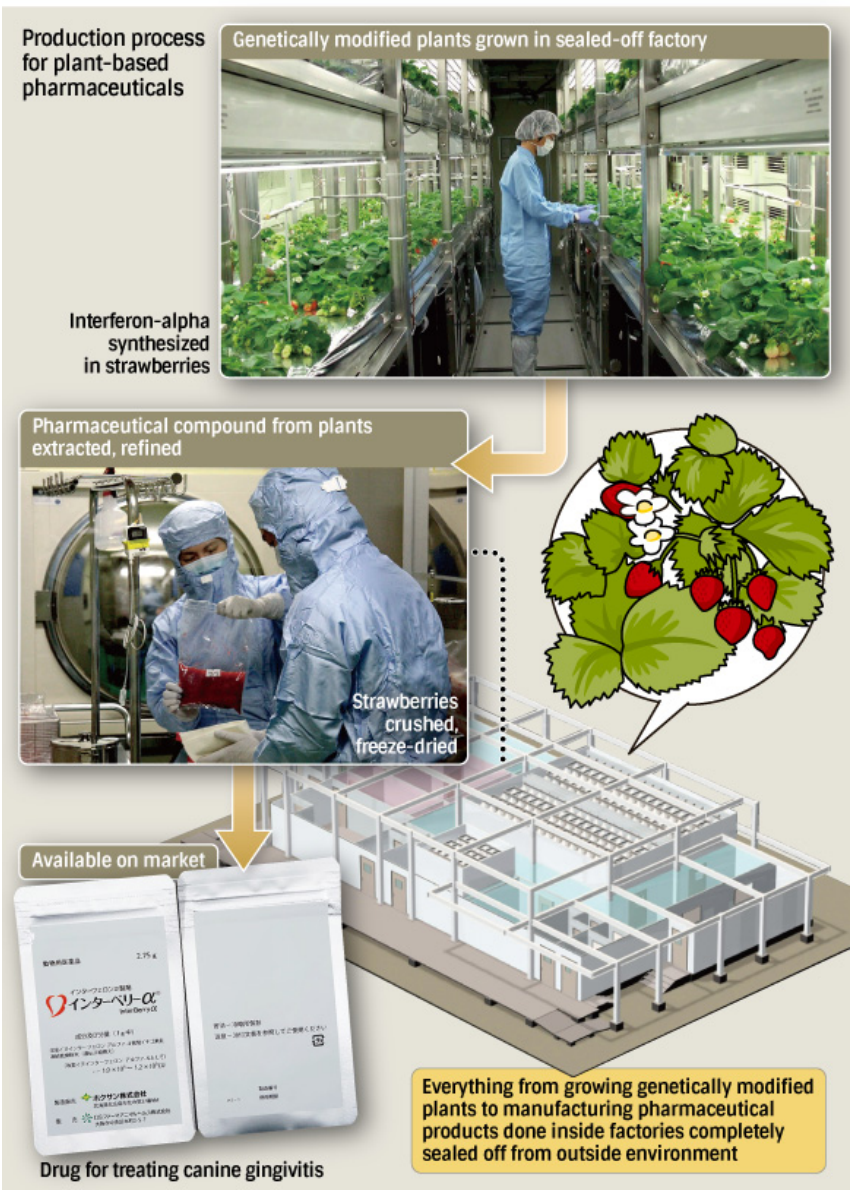

Fig. 1. The world's first pharmaceutical based on an ingredient made from a genetically modified plant. Production process for plant-based pharmaceuticals: Interferon-alpha synthesized GM strawberries. (Source: AKIHIKO NISHIYAMA, NIKKEI Asian Review. June 09, 2014.)
로서 살충제로 제어하는 방법 밖에 없는데 살충제도 매우 비효과 적이어서, 심한 경우 살충제 살포 횟수가 80회에 달하는 경우도 있다. 이 문제의 해결을 위해 방글라데시 국가농업연구소는 국제 협력을 통해 해충저항성 GM 가지를 개발하여 2013년 안전성심 사를 완료한 후 즉시 상업화를 진행하였다. 상업화 원년인 2014 년에는 $2 \mathrm{ha}$ 에서 20 명의 농부가 재배했으나 2016년에는 2,500명 의 농부가 $700 \mathrm{ha}$ 에서 재배하는 등 기하급수적 증가를 보여주었 다. 2017 년에는 2016 년의 $242 \%$ 인 $2,400 \mathrm{ha}$ 를 재배하였고 2018 년에는 $2,975 \mathrm{ha}$ 로 재배지역이 증가되는 등 엄청난 증가세를 보였다(Table 2). 2016년까지의 재배결과 분석에 따르면 GM가 지 재배농가의 경우 수확량이 $30 \%$ 이상 증가했으며, 살충제 사용을 $70-90 \%$ 감소시켜서 일반 가지에 비해 ha 당 1,868 달러의 경제적 이익을 가져왔다고 보고되었다. 이 해충저항성 $\mathrm{GM}$ 가지는 국가 의 과감한 신기술도입 정책결정으로 농가의 애로사항을 빠르게 해결해준 대표적 사례로 알려지고 있다(ISAAA Brief 53. 2018, ISAAA Brief 54. 2019, Kim et al. 2018, Kim et al. 2019)

\section{사료용/식품가공용에서 식용으로 확대}

1세대 $\mathrm{GM}$ 작물은 $\mathrm{GM}$ 면화, $\mathrm{GM}$ 콩, $\mathrm{GM}$ 옥수수 등 식용이 아닌 의류 원료, 사료 및 식품첨가용으로 사용되도록 개발되었다. 반면 최근 주곡 작물에 대한 $\mathrm{GM}$ 작물 개발이 각 국가별로 활발히 진행되고 있다. 벼, 옥수수, 감자, 밀 등 지구상의 인류를 먹여 살리는 주곡은 지속적인 개량을 통해 식량을 공급해오고 있다. 인구증가와 기후변화에 대응한 가장 큰 도전은 이러한 주곡의 안정적 공급일 것이며 이러한 이유로 주곡에 대한 각국의 생명공 학기술 적용 연구는 지속되고 있다. 현재 전문가들은 가장 첫 번째 $\mathrm{GM}$ 주곡작물의 상업화 후보로 쌀을 전망하고 있으며 실제 로 쌀에 대한 상업화 연구는 국가 간 경쟁적으로 진행되고 있다. 중국의 경우 이미 2009년에 자체 개발한 해충저항성 $\mathrm{GM}$ 벼의 안전성심사를 통해 식용/사료용/재배용 승인을 한 바 있다. 일본

Table 2. Adoption of IR brinjal in Bangladesh, 2018

\begin{tabular}{ccccc}
\hline Year & $\begin{array}{c}\text { Adoption of IR brinjal } \\
\text { (ha) }\end{array}$ & $\begin{array}{c}\text { Total brinjal area } \\
\text { (ha) }\end{array}$ & $\begin{array}{c}\text { No. of IR brinjal } \\
\text { farmers }\end{array}$ & $\begin{array}{c}\text { Adoption rates } \\
(\%)\end{array}$ \\
\hline 2014 & 12 & 50,000 & 120 & $<1$ \\
2015 & 25 & 50,000 & 250 & 2 \\
2016 & 700 & 50,000 & 2,500 & 5 \\
2017 & 2,400 & 50,000 & 27,000 & 6 \\
2018 & 2,975 & 50,000 & 34,500 & 6 \\
\hline
\end{tabular}

(Source: ISAAA Briefs 54) 
도 이미 쌀 소비촉진 및 수요확대를 목적으로 2010년부터 정부주 도로 다양한 형질의 GM 벼 개발을 추진하고 있으며, 2020년까지 삼나무앨러지 예방용 $\mathrm{GM}$ 쌀을 상업화한다고 공식 선언한바 있다. 이외에도 일본에서는 최근 특정 살균제와 접촉이 이루어질 때까지 개화하지 않는 $\mathrm{GM}$ 벼를 개발하는 등 다양한 연구를 통해 $\mathrm{GM}$ 쌀에 대한 기술력을 적극적으로 선점하고 있다(Kim et al. 2018, Kim et al. 2019). 이밖에 다른 국가들도 GM 쌀 연구개발에 적극 나서고 있다. 벨기에는 비타민 B군에 속하는 수용성 비타민인 엽산이 강화된 $\mathrm{GM}$ 쌀 을 개발 중이며, 호주 에서도 철분과 아연이 현저히 늘어난 $\mathrm{GM}$ 쌀을 개발했다고 보고 하였다. 재배 과정에서 온실가스를 거의 생산하지 않는 새로운 $\mathrm{GM}$ 벼도 개발 중이다. 미국 국립연구소는 스웨덴, 중국의 과학자 들과 함께 메탄을 거의 발생시키지 않으면서도 쌀의 수확량을 증가시킨 벼를 개발했다고 과학 전문지 “네이처(Nature)"에 발 표했다. 이 연구는 지구 온난화 문제 해결에 기여할 수 있다는 점이 높이 평가되면서, 미국의 과학전문지 “파퓰러 사이언스 (Popular science)”의 '2015년 가장 뛰어난 과학 프로젝트' 중 하나로 선정되기도 했다(Kim et al. 2018)

비타민 A 전구체인 베타카로틴을 생산하는 GM 황금벼는 2019년 12월 필리핀에서 최초로 재배승인이 이루어졌다. 또한, 방글라데시의 농업부 장관도 2019년부터 GM 황금벼의 재배승 인이 곧 이루어져 2020년부터 출시예정이라고 발표한바 있어 2020년부터 주곡작물로는 최초로 상업용 재배가 이루어질 것으 로 보고되었다(Rosalie 2019). 이 황금쌀의 재배는 방글라데시 국민들의 비타민 $\mathrm{A}$ 부족 문제를 해결할 수 있어서 매우 중요하다 고 한다. 세계보건기구에 따르면 방글라데시의 취학 전 아동 5 명 중 1명은 비타민 A가 부족한 반면 임신부의 $23.7 \%$ 는 비타민 $\mathrm{A}$ 가 부족한 것으로 나타났다. 이러한 이유로 방글라데시 정부는 적극적인 농업생명공학기술 수용정책을 통해 국가의 비타민 $\mathrm{A}$ 결핍 퇴치에 노력하고 있는 것이다. 이 황금쌀은 미국, 캐나다, 호주, 뉴질랜드에서 이미 식품용으로 허가를 받은바 있으며, 이번에 필리핀에서 재배승인이 되면서 1999년 개발된 이후 대략 20 년 만에 상업화가 이루어지는 것이다. 이에 전문가들은 향후 많은 국가에서 식량작물에서의 생명공학기술 상용화가 확산될 것으로 전망하고 있다.

서구의 주식인 밀에 대한 연구개발도 활발히 진행 중에 있다. 미국의 경우 국가 연구소 및 대학에서 다양한 $\mathrm{GM}$ 밀 연구개발을 수행하고 있다. 특히, 밀 재배 농가들의 지속적인 상업용 $\mathrm{GM}$ 밀 개발 요구에 따라, 일부 다국적 기업에서 제초제내성, 가뭄내 성, 병해충저항성 상업용 $\mathrm{GM}$ 밀 개발을 진행 중인 것으로 알려져
있다. 호주와 유럽에서도 연구개발이 활발히 진행되고 있다. 호주국립과학원(CSIRO)은 질병저항성 및 가뭄내성과 오일 함 량이 높은 GM 밀을 개발하고 이에 대한 시험재배를 2017년부터 시작할 계획이다. 영국의 에식스 대학, 랭커스대학교, 로담스테 드 연구소의 공동 연구팀은 광합성 효율을 증진시켜 생산량을 증대시키는 $\mathrm{GM}$ 밀을 개발했다. 이 $\mathrm{GM}$ 밀은 온실 시험에서 생산량이 $40 \%$ 까지 증가되는 것이 확인되어 최종 확인을 위한 시험재배를 실시할 계획이라고 한다. 쌀과 함께 주식으로 밀 소비가 많은 중국의 경우도 국가 차원에서 2020년까지 상업용 $\mathrm{GM}$ 밀 개발기술을 확보한다는 정부 농업기술 개발정책을 발표 한 바 있다. 이처럼 밀을 주식으로 하는 각 국가에서는 식량공급 안정화를 위한 $\mathrm{GM}$ 밀 연구개발을 지속적으로 추진하고 있다 (Kim et al. 2018, Kim et al. 2019).

이상과 같이 각 국가에서는 자국의 주식에 대한 공급 안정화와 미래 우수 육종소재 확보를 위한 $\mathrm{GM}$ 작물 개발에 노력하고 있다. 이러한 노력과 함께 일부 국가에서는 이미 개발된 $\mathrm{GM}$ 주곡작물 에 대한 상업화 검토가 이루어지고 있는 것으로 전해지고 있다. 하지만 $\mathrm{GMO}$ 기술로 육성된 주곡작물에 대한 상업화는 기술수 요 만의 문제가 아닌 사회적 정서 등 여러 가지 관점에서의 논의와 검토가 필요한 만큼 현재도 그렇지만 앞으로도 많은 논란이 예상된다.

\section{국내 GM작물 연구개발 현황}

우리나라의 경우 2001년부터 시작된 작물기능유전체사업과 바이오그린21사업을 통한 농업생명공학연구 활성화로 $\mathrm{GM}$ 작물 연구개발 건수가 급속 증가하면서 형질전환기술, 유전자개발 기술 등 주요 기술력을 확보하기 시작하였다. 이들 중 농약사용량 을 줄이면서 해충피해를 방지할 수 있는 해충저항성 작물 등 1 세대 $\mathrm{GM}$ 작물 개발에 성공함으로써 우리 농업의 어려움 해결을 위한 농업생명공학기술의 활용가능성을 확인시켜 주었다. 이와 함께 비타민 $\mathrm{A}$ 성분이 보강된 황금쌀과 함께 시력개선 및 노화방 지용 기능성 컬러쌀 등 소비자에게 혜택을 주는 2세대 $\mathrm{GM}$ 작물 개발도 순차적으로 성공을 거두는 등 첨단농업기술에 대한 국가 기술경쟁력 확보가 가능하다는 것도 증명해 보여 주었다. 미래 기후변화에 대비한 작물 개발도 좋은 성과를 거두었는데, 국내 연구진이 개발한 가뭄내성 벼의 경우 그 유전자의 우수성을 인정받아 외국 종자회사들로부터 기술이전 계약의 성과를 거두 는 등 글로벌 종자시장 진출의 가능성도 확인한 바 있다(Park 2014, Park 2017). 이러한 기술력 확보에는 농업생명공학연구를 
통한 우리 농업의 첨단산업화를 지향하는 정부의 정책의지가 큰 몫을 담당하였다. 특히, 과학기술부와 농촌진흥청이 공동 지원하는 프론티어 21 사업의 작물기능유전체사업과 농촌진흥청 의 바이오그린 21 사업 추진이 농업생명공학 기반구축에 큰 힘이 되었다고 볼 수 있다.

위에 소개한 대부분의 $\mathrm{GM}$ 작물들은 상업용으로 개발된 $\mathrm{GM}$ 작물은 아니다. 다만, 생명공학기술을 통해 우리나라의 주요 작물들을 보다 유용하게 개선할 수 있다는 것을 보여준 연구결과 일 뿐이다. 연구용과 상업용은 개발 목적부터 개발과정까지 엄연 히 차이가 있으며 상업용 $\mathrm{GM}$ 작물의 경우 안전성평가와 심사에 적합하게 만들기 위한 엄청난 노력과 투자가 요구된다. 즉, 목표 로 하는 형질을 개선하는데 필요한 유전자를 선발하기 위하여 유전자 기능 검정용 $\mathrm{GM}$ 작물을 육성하게 되는데, 이렇게 육성된 연구용 $\mathrm{GM}$ 작물에서 우리가 원하는 형질이 개선되는 것이 확인 될 경우 그 유전자를 이용하여 안전성심사 통과가 가능한 상업용 GM작물을 새롭게 육성하는 것이다(EFSA GMO Panel 2008, Kim et al. 2009, Lee 2011, Slot et al. 2018). 이와 같은 이유로 앞에서 기술한 연구용 GM작물들 중에서 목표형질이 확실히 개선된 일부는 향후 상업화가 가능하도록 안전성심사기준에 맞게 새롭게 만들어지고 있으며, 일부 작물들은 조만간 안전성평 가를 추진할 계획으로 있다. 이와 같이, 우리의 경우 아직까지 상업화에 필요한 안전성 심사가 통과된 국내 개발 $\mathrm{GM}$ 작물은 1 건도 없는 실정이다. 즉. 선진국 대비 상용화 $\mathrm{GM}$ 작물 기술력 확보가 매우 미흡하며 이에 따라 향후 다가올 $\mathrm{GM}$ 작물 상용화 시대에 대비한 준비가 매우 부족한 것이다.

이미 설명한 것처럼 $\mathrm{GM}$ 작물은 기존 육종기술로 해결이 어려 운 농업현장의 문제를 극복해 줄 수 있는 최첨단 농업기술로서 국가 경쟁력 차원에서 필히 확보할 국가 핵심기술인 반면, 많은 국민들이 안전성에 대한 우려를 보이는 것도 사실이다. 또한 막대한 연구비 투자와 고도의 생명공학기술을 적용함과 동시에 일반 육종 품종과는 달리 철저한 안전성 평가와 엄격한 안전성심
사라는 승인 절차를 거쳐야 하므로, 이들의 개발과 실용화를 위한 전략적 접근과 적정한 방향 정립이 매우 중요하다. 이런 차원에서 $\mathrm{GM}$ 작물은 소비자나 수요자의 요구도 중요하지만 안 전성 기준을 잘 고려하여 개발하는 것이 무엇보다 더 중요할 것이다. 이에 농촌진흥청에서는 2011년부터「 $\mathrm{GM}$ 작물개발사업 단」을 출범시켜 안전성 기준에 맞고 소비자와 수요자가 필요로 하는 $\mathrm{GM}$ 작물 개발에 본격적인 노력을 기울였다. 이 $\mathrm{GM}$ 작물개 발사업단은 농촌진흥청의 농업생명공학 및 작물육종 연구기반 을 중심으로 대학, 국공립연구소, 민간기업의 전문연구팀이 공동 으로 국내 농업의 어려움을 해소할 국내용 고부가 $\mathrm{GM}$ 작물과 함께 글로벌 종자시장에 진출할 글로벌 $\mathrm{GM}$ 작물을 산학관연 공동으로 개발해 왔다.

당시 사업단의 연구개발 전략은 크게 3 가지였다. 첫째로 우리 농업발전에 기여하고 소비자/수요자가 공감할 목표를 설정하고, 둘째로 국내용 $\mathrm{GM}$ 작물은 향후 소비자의 필요 시 제공을 위해 육종재료 확보 및 기술력 확보에 주력하고, 마지막으로 세계 종자시장을 공략할 글로벌용 $\mathrm{GM}$ 종자를 개발하여 세계 종자시 장에 진출하는 것이었다. 이러한 전략에 따라 2017년까지 GM작 물개발사업단에서는 미래 상용화 대비 국내용 GM작물 유용 이벤트 12작물 81종을 Table 3과 같이 육성하였다. 이들 중에는 농업의 어려움 해결이 가능한 병해충 저항성 작물, 기후변화 대응 가뭄내성 작물, 고품질 및 기능성이 추가된 고부가 작물과 함께 우리 농업을 첨단 생명산업으로 전환이 가능한 고부가 산업소재생산 작물 등을 포함하고 있다(Park 2017, Park et al. 2018). 이 작물들은 특허에서 가능한 자유롭고 안전성심사 기준 에 맞게 새롭게 제작된 것들로 유사시 육종재료로 활용이 가능한 것 들이다.

\section{상업용 GM작물 개발 기술 경쟁력 확보를 위한 노력}

$\mathrm{GM}$ 작물의 경우 상용화를 위해서는 엄청난 분량의 안전성평

Table 3. GM crops (events) developed through the NCGC program

\begin{tabular}{|c|c|c|c|c|c|c|c|c|}
\hline \multirow{2}{*}{ Target trait } & \multicolumn{7}{|c|}{13 crops } & \multirow{2}{*}{ Total } \\
\hline & Rice & Soybean & Chinese cabbage & Red pepper & Flower & Glass & Others & \\
\hline Abiotic stress tolerance & 13 & 1 & 2 & & 1 & & & 17 \\
\hline Biotic stress resistance & 9 & 4 & 3 & 3 & 2 & & 3 & 24 \\
\hline High yield/labor save & 13 & 4 & & & & 2 & 3 & 22 \\
\hline Quality/value enhancing & 9 & 4 & 2 & & 2 & & 1 & 18 \\
\hline Total & 44 & 13 & 7 & 3 & 5 & 2 & 7 & 81 \\
\hline
\end{tabular}

(From「National Program for Developing Biotech Crops in Korea」 PBB, 2018) 
가(식품 및 환경위해성)를 실시하고 그 결과를 관련 정부 부처에 서 주관하는 안전성심사위원회에서 다양한 분야의 전문가들이 엄격한 심사를 통과해야 상업화를 승인해 준다. 이러한 이유로 $\mathrm{GM}$ 작물의 안전성은 인류가 지금까지 경험해온 그 어떤 작물보 다도 더 철저한 평가와 검증과정을 거치며 개발된다고 전문가들 로부터 인정을 받고 있다(Fig. 2).

이에 $\mathrm{GM}$ 작물개발사업단에서는 미래 대비 $\mathrm{GM}$ 작물 상용화 기술기반 구축 및 성공사례 도출을 위해, 현재까지 개발된 유용 $\mathrm{GM}$ 작물 중에서 안전성 심사기준을 충족시키는 최종 후보인 10 종을 선발하여 Table 4와 같이 안전성평가를 실시하여 왔다 (Park 2017, Park et al. 2018). 국내의 경우 안전성심사가 통과되 더라도 국민정서상 당장의 상용화는 어려울 것이다. 하지만, 안전성평가를 통해 개발된 $\mathrm{GM}$ 작물의 안전성이 검증될 것이며 우리도 상용화 $\mathrm{GM}$ 작물 기술력을 확보한 것으로 인정받을 수

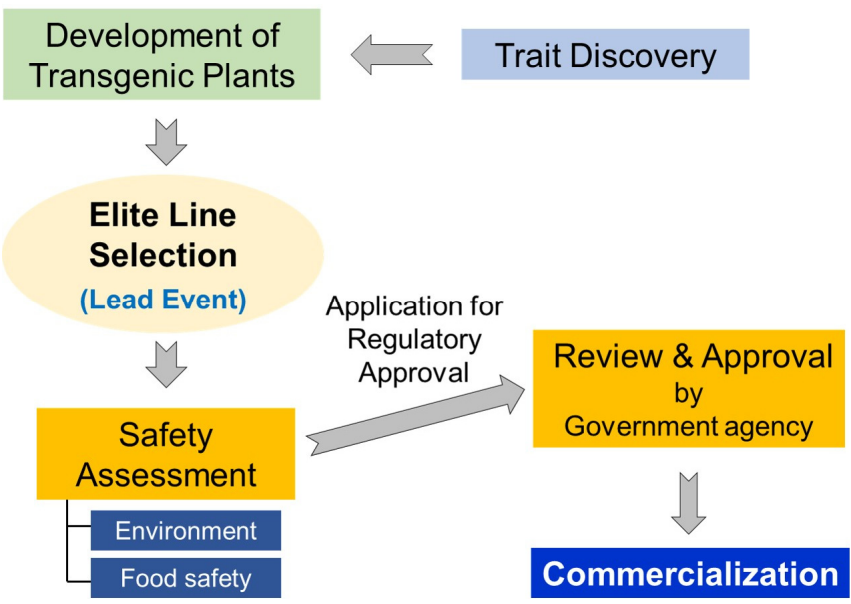

Fig. 2. Process for commercialization of GM crop

Table 4. Safety assessment completed GM crops (events)

\begin{tabular}{lll}
\hline \multicolumn{2}{c}{ Event } & \multicolumn{1}{c}{ Target trait } \\
\hline Crops & Rice & $\begin{array}{l}\text { Drought tolerance } \\
\text { Insect resistance } \\
\end{array}$ \\
& Resveratrol-enrich \\
Soybean & Produce a protein raw material for cosmetics 1 \\
& Produce a protein raw material for cosmetics 2 \\
& Produce a protein raw material for cosmetics 3 \\
Red pepper & Virus resistance \\
Grass & Herbicide-tolerance with male-sterility \\
& Herbicide-tolerance \\
Rice stem cell & Resveratrol-enrich
\end{tabular}

(From`National Program for Developing Biotech Crops in Korea」 PBB, 2018)
있을 것이다. 안전성평가가 진행된 $\mathrm{GM}$ 작물 중 제주대학교 연구 팀이 개발한 제초제내성 $\mathrm{GM}$ 잔디의 경우 2014년 1월에 안전성 심사를 신청하여 현재 심사가 진행 중에 있다(Bae et al. 2011, Park et al. 2018). 다른 작물과 마찬가지로, 잔디의 경우도 잡초발 생이 많아 제초작업에 많은 농약 및 노동력이 소요되고 있는 등 잡초관리에 많은 고생을 겪고 있다. 만약, 제초제내성 $\mathrm{GM}$ 잔디가 안전성심사를 통과하여 상용화가 될 경우, 제초제 사용량 과 노동력 절감을 통해 잡초관리 비용을 $1 / 5$ 로 줄일 것으로 예상되어 국내 잔디관리 애로사항 해결에 크게 기여할 것으로 기대되고 있다. 현재 심사 중인 이 $\mathrm{GM}$ 잔디의 경우 비 식용이며 돌연변이 처리로 인한 웅성불임으로 화분이동이 방지되는 점 등이 국민들의 거부감 완화에 도움이 될 것으로 평가되고 있다. 이러한 이유로 이 제초제내성 $\mathrm{GM}$ 잔디가 우리 기술로 국내에서 개발되어 안전성심사를 통과한 최초의 상업용 $\mathrm{GM}$ 작물이 될 것으로 전문가들은 전망하고 있다.

\section{향후 전망 및 결론}

향후, 국내 $\mathrm{GM}$ 작물 개발은 그 동안 확보한 기술 파이프라인과 유용 재료를 활용할 경우 보다 효과적이고 실용적으로 연구개발 추진이 가능할 것으로 전망된다. 특히 안전성평가와 심사에 대한 경험이 쌓이면서 안전성심사기준을 충족하는 유용 $\mathrm{GM}$ 작물들이 개발됨으로써 국내 농업현장의 어려움 해결 가능성을 보여줄 것으로 전망된다. 하지만 $\mathrm{GM}$ 작물 상용화에 반대가 심한 국내 정서상 당장의 상용화 보다는 미래 대비 기술기반 구축에 지속적 인 노력을 하면서 국민 공감대 형성이 가능한 상용화 방안 도출에 노력할 것으로 전망된다. 반면, 글로벌 시장 진출용 $\mathrm{GM}$ 작물의 경우 보다 적극적으로 추진될 것으로 전망된다. 글로벌 시장진출 용 형질전환작물의 주요 목표형질은 가뭄내성, 다수확, 질소비료 저감 등이며 글로벌 곡물시장의 주요 품목인 옥수수와 콩 등이 대상작목이 될 것이다. 현재 많은 연구팀들이 글로벌 $\mathrm{GM}$ 종자에 투입 가능한 고유 유전자 개발에 노력하고 있으며, 일부 연구팀은 개발된 유전자를 다국적기업과 공동으로 글로벌 작물인 콩, 옥수 수 등에 도입하여 그 기능을 검증하는 단계에 있다. 이러한 연구 노력은 향후 글로벌 $\mathrm{GM}$ 종자 개발의 성공으로 나타날 것으로 기대된다. 국내 $\mathrm{GM}$ 곡물 수입은 매년 2 3조원에 이르는 막대한 양이다. 이를 대체하기 위한 방안은 결국 자체 $\mathrm{GM}$ 종자 개발을 통해 해외재배 후 도입 등의 노력이 필요하며, 더 나아가서 우수 한 글로벌 $\mathrm{GM}$ 종자 자체 개발을 통해 세계 종자시장을 진출하는 능동적이고 적극적인 노력이 필요하다고 본다. 
이와 같이 우리나라의 생명공학연구는 정부의 지속적인 정책 지원과 많은 국내 연구원들의 노력의 결과로 짧은 기간 동안 기초분야와 응용분야 모두 세계와 경쟁이 가능한 기술기반을 확보하였고, 유사시 언제라도 농업 현장에 투입이 가능한 실용화 성과도 확보한 것으로 평가 된다. 하지만 아직 선진국과의 기술격 차가 있으며 이를 추월하기 위해서는 더욱 적극적이고 지속적인 투자와 함께 국내외 상황을 감안한 보다 전략적인 노력이 필요하 다고 본다. 방글라데시에서 $\mathrm{GM}$ 황금벼 재배가 곧 승인될 것을 기점으로 고부가 $\mathrm{GM}$ 작물의 상업화가 확장될 것으로 전망된다.

이런 상황에서 $\mathrm{GM}$ 작물도 국내 상용화가 어려운 우리의 현실 을 감안한 연구개발 전략을 아래와 같이 추진하는 것이 필요하다. 첫째, 국내용 GM작물은 미래대비 육종소재 확보 및 산업소재 생산용으로 연구개발을 추진하는 것이 바람직하다. 즉 주곡의 경우 재배가 아닌 미래 대비 육종소재 확보와 기술경쟁력 확보를 위한 연구개발을 추진하고, 산업소재 생산용 작물은 일본과 같이 밀폐시설에서 산업소재를 생산하여 상업화를 추진하는 전략적 연구가 필요하다. 두 번째로, 글로벌 종자시장 진출용 $\mathrm{GM}$ 작물은 국내 연구개발과 병행하여 해외 연구기지 구축을 통한 상업용 $\mathrm{GM}$ 종자 개발과 글로벌 시장 진출이라는 전략적 상업화 추진이 필요하다. 즉, 가뭄 내성이나 질소이용 효율 제고 등 글로벌 수요가 형질을 대상으로 세계 종자시장 점유율이 큰 콩, 옥수수를 대상으로 해외에서 연구개발과 상업화를 적극적으로 추진하는 것이 효과적일 것이다. 이러한 전략적 추진이 국내 상용화가 어려운 $\mathrm{GM}$ 작물의 미래 대비 연구개발 기술력 유지 발전과 함께 농업생명공학기술을 활용한 농업의 첨단산업화 달성에 필요할 것으로 사료된다.

\section{적 요}

전 세계 $\mathrm{GM}$ 작물 재배면적은 2018년에도 계속 증가하여 1억 1,170 만 ha에 도달했다. 26 개국은 재배를 승인했으며, 추가 44 개국 $(18+26 \mathrm{EU}$ 국가)은 공식적으로 식품, 사료 및 가공을 위해 생명공학 작물을 수입했다. 이는 GM작물이 이미 전 세계적 으로 수용되고 있음을 의미한다. 1세대 GM 종자는 미국과 유럽 등 글로벌 농업 회사가 주도적으로 연구개발과 상업화를 주도하 고 있다. 20 년 동안 상용화 된 1세대 $\mathrm{GM}$ 종자의 $90 \%$ 이상이 해충저항성과 제초제내성이라는 사실은 이들이 농업 생산성 향상과 농민 소득증대에 지속적으로 영향을 미치고 있음을 증명 하고 있다. 이와 같이 GM작물의 효과 입증과 함께 기술이 점차적 으로 발전됨에 따라 최근 $\mathrm{GM}$ 작물 연구개발 추세가 변화되고
있다. 즉, 생산자 중심에서 농민과 소비자 모두에게 이익이 되는 방향으로 연구개발과 상업화로 점차 그 범위가 확대되고 있다. 우리나라에서는 세계적인 생명공학작물 기술개발 경쟁에서 뒤쳐 지지 않기 위하여 농촌진흥청이 주관한 차세대바이오그린21사 업의 7개 프로그램 중 하나인 GM작물개발사업(National Center for GM Crops, NCGC) 프로그램을 산학연 공동으로 2011년부 터 추진하여 미래 우리 농업의 문제를 해결하기 위해 활용될 유용 생명공학 작물을 개발하여 왔다. 이에, 현재 진행되고 있는 글로벌 및 국내 GM작물 개발 및 상업화 현황과 함께 향후 전망을 소개하고자 한다.

\section{사 사}

본 연구는 농촌진흥청 차세대바이오그린21사업(세부과제번 호: PJ01367503)의 지원에 의해 수행되었음.

\section{REFERENCES}

1. Bae TW, Kang HG, Song IJ, Sun HJ, Ko SM, Song PS, Lee HY. 2011. Environmental risk assessment of genetically modified herbicide-tolerant zoysiagrass (Event: Jeju Green21). J Plant Biotechnol 38: 105-116.

2. Cho JI, Lee GS, Park SC. 2016. Global status of GM crop development and commercialization. J Plant Biotechnol 43: 147-150.

3. EFSA GMO Panel. 2008. Safety and nutritional assessment of GM plants and derived food and feed: The role of animal feeding trials. Food Chem Toxicol 46(Supplement 1): S2-S70.

4. ISAAA Brief 53. 2018. Global Status of Commercialized Biotech/GM Crops in 2017.

5. ISAAA Brief 54. 2019. Global Status of Commercialized Biotech/GM Crops in 2018.

6. Kim CG, Jeong SC, Yoon WK, Park KW, Choi KH, Kim HM. 2009. Development of genetically modified crops based on considerations of risk assessment and management. J Plant Biotechnol 36: 360-365.

7. Kim SM, Lim SM, Park SC. 2018. Global Trends of Biotech Crops in 2018. Korea Biotechnology Information Center (KBIC).

8. Kim SM, Lim SM, Park SC. 2019. Global Trends of Biotech Crops in 2019. Korea Biotechnology Information Center (KBIC).

9. Lee SW. 2011. Strategies for the development of GM crops 
in accordance with the environmental risk assessment (I). J Plant Biotechnol 38: 125-129.

10. Park SC. 2014. Research Performance Report of the National Center for GM Crops (2011-2014).

11. Park SC. 2017. Research Performance Report of the National Center for GM Crops (2015-2017).

12. Park SH, Cho JI, Kim YS, Kim SM, Lim SM, Lee GS, Park SC. 2018. National Program for Developing Biotech
Crops in Korea. Plant Breed Biotech 6: 171-176.

13. Rosalie E. 2019. Still waiting for approval to plant golden rice. AgWEB Nov 24.

14. Slot MM, van de Wiel CCM, Kleter GA, Visser RGF, Kok EJ. 2018. The assessment of field trials in GMO research around the world and their possible integration in field trials for variety registration. Transgenic Res 27: 321-329. 